\title{
Recombinant Oncostatin M
}

National Cancer Institute

\section{Source}

National Cancer Institute. Recombinant Oncostatin M. NCI Thesaurus. Code C1180.

A recombinant $26.0 \mathrm{kDa}$ protein, containing 227 amino acid residues, a member of the cytokine family and growth and differentiation factor that participates in the regulation of neurogenesis, osteogenesis and hematopoiesis. Produced by activated T cells, monocytes and Kaposi's sarcoma cells, oncostatin M (OSM) can exert both stimulatory and inhibitory effects on cell proliferation. It stimulates the proliferation of fibroblasts, smooth muscle cells and Kaposi's sarcoma cells, but inhibits the growth of some normal and tumor cell lines. It also promotes cytokine release (e.g. IL-6, GM-CSF and G-CSF) from endothelial cells, and enhances the expression of low-density lipoprotein receptor in hepatoma cells. 